\title{
Ketones as Electrophile in Nitroaldol Reaction: Synthesis of $\beta, \beta$-Disubstituted- 1,3-dinitroalkanes and Allylic Nitro Compounds
}

\author{
Alex O. Gomes, ${ }^{\circledR a}$ Douglas L. F. de Souza, ${ }^{a}$ Jeronimo S. Costa ${ }^{b}$ and \\ Vera Lúcia P. Pereira ${ }^{\circledR *, a}$ \\ ${ }^{a}$ Laboratório de Síntese Estereosseletiva de Substâncias Bioativas, \\ Instituto de Pesquisa de Produtos Naturais, Universidade Federal do Rio de Janeiro, \\ 21941-902 Rio de Janeiro-RJ, Brazil \\ ${ }^{b}$ Instituto Federal de Educação, Ciência e Tecnologia do Rio de Janeiro, \\ 26530-060 Nilópolis-RJ, Brazil
}

$\beta, \beta$-Disubstituted-1,3-dinitro compounds were obtained exclusively with an overall yield of $83 \%$ through a domino nitroaldol/elimination/1,4-addition process, when excess nitromethane was added to cyclohexanone or butanone using DBU (1,8-diazabicyclo[5.4.0]undec-7-ene), as a basic catalyst. On the other hand, $\beta$-nitroalcohols could be obtained in $30-84 \%$ yield, when nitromethane reacts with different aliphatic ketones in stoichiometric amounts, in the presence of catalytic amounts of $\mathrm{K}_{2} \mathrm{CO}_{3(\mathrm{~s})}$, Amberlyst ${ }^{\circledR}$-A21 or TBAF. $3 \mathrm{H}_{2} \mathrm{O}$ (tetra- $n$-butylammonium fluoride trihydrate)/THF (tetrahydrofuran). In addition, a new and versatile route to obtainment of allylic nitro compounds, by treatment of acetylated nitroalcohols and aldehydes in catalytic amounts of DBU or TBAF. $3 \mathrm{H}_{2} \mathrm{O}$, via a one-pot elimination/nitroaldol reaction sequence, was developed.

Keywords: allylic nitro compounds, DBU, domino reaction, reaction reversible, Michael addition, Henry reaction

\section{Introduction}

The nitroaldol reaction (Henry's reaction) is one of the most important reactions used to form $\mathrm{C}-\mathrm{C}$ bonds. It is carried out under action of an alkyl nitronate anion on an aldehyde or ketone, producing $\beta$-nitroalcohols. Henry's reaction is generally very easy to perform, it is catalyzed by a large number of different basic homogeneous or heterogeneous systems, it occurs at room temperature in the presence of different organic solvents, water or without solvent. ${ }^{1-19}$ The $\beta$-nitroalcohols produced are useful building blocks that carry the synthetically versatile nitro and hydroxyl groups. $\beta$-Nitroalcohols have been used as precursors in the synthesis of different compounds such as nitroalkenes, $\beta$-aminoalcohols, $\alpha$-amino acids, hydroxycarboxylic acids, $\alpha$-nitroketones, among others. In particular, the use of ketones as electrophiles in nitroaldol reactions is more limited than aldehydes, not only because of the lower electrophilicity generated by the electronic and steric effects of $\alpha, \alpha^{\prime}$-carbonyl substituents, but also

*e-mail: verapatrocinio@protonmail.com due to the inherent high reversibility of the reaction. ${ }^{20-23}$ Generally, low-yield nitroalcohols, self-condensing adducts or a complex mixture of products are obtained depending on the proportion of reagents, strength of the base, reaction time and temperature. ${ }^{24-31}$ Thus, it is possible to find in literature yields in the formation of $\beta$-nitroalcohols varying from low to excellent, using the same ketone under the same reaction conditions.

1,3-Dinitro alkanes have gained importance in synthesis organic for preparation of different targets such as 1,3-diketones, 1,3-diamines, polyfunctionalized carbacycles, highly substituted arenes, phenols, among others. ${ }^{32-36}$ They are usually prepared in two ways: the first one occurs by adding nitronate anions to conjugated nitroalkenes produced from aldehydes. In this case, undesirable oligomerization products can be formed under basic conditions, especially if low molecular weight nitroalkenes are used.

The second way consists in the reaction of aldehydes or ketones with excess nitroalkane, under catalysis of specific bases leading to $\beta$-alkylates- and $\beta, \beta$-alkylated1,3-nitroalkanes, respectively. The synthesis occurs in 
the same reaction vessel, via a domino Henry reaction/ dehydration/Michael addition sequence. ${ }^{34}$ The synthesis of $\beta, \beta$-alkylated-1,3-nitroalkanes are scarcely studied, due mainly the high tendency to the reversibility of the nitroaldol reaction in ketone.

Allylic nitro compounds have received much attention in the last decades because of the versatility of its functional groups. ${ }^{37-54}$ Its structural arrangement consists of alkenes bearing nitro alkyl substituents. Allylic nitro compounds can be obtained by nucleophilic substitution reactions with nitrite anion, ${ }^{37}$ ipso substitution of carboxylic acids, ${ }^{38}$ Michael addition of alkyl nitronates to alkynes, ${ }^{39}$ and by the alkene isomerization of Baylis-Hillman adducts. ${ }^{40,41}$ They can be also obtained as byproduct from $\beta$-nitroalcohol related adducts. Its reactivity is similar to the alkenes and to the nitroalkanes. Thus, they take part in addition reactions (Henry and Michael reactions), are reduced to amines, transformed in conjugated oximes and nitriles, ${ }^{42}$ allylic amines ${ }^{43}$ and conjugated carbonyl compounds by Nef reaction. ${ }^{45,46}$ They undergo elimination of nitrous acid or nitrite leading to allylic carbocations which were employed in the synthesis of dienes, naphtalenes and allylic sulfones. ${ }^{47}$ They also undergo nucleophilic substitution of the nitro group by action of soft nucleophiles releasing nitrite anion. ${ }^{48,49}$ Allylic substitution can occurs internally in some conditions. Thus, a sigmatropic rearrangement converts the allylic nitro compound in the respective gamma-nitrite allyl compound that can be converted in allyl alcohols by hydrolysis. ${ }^{50,51}$ They have been also used as nitrite donors, ${ }^{52}$ undergo allylic alkylation palladiumcatalysed $^{44,53}$ and also serve as suitable allyl compounds for the Heck-Matsuda reaction. ${ }^{54}$

Based in our continuing interest to employ nitroalkanes as raw-material for obtainment of useful chiral and achiral synthetic intermediates and chiral natural products, ${ }^{55-66}$ we now desire to relate our found about the reactivity of representative ketones, in nitroaldol reaction, employing
DBU (1,8-diazabicyclo[5.4.0]undec-7-ene $)^{67}$ and TBAF. $3 \mathrm{H}_{2} \mathrm{O}$ (tetra- $n$-butylammonium fluoride trihydrate) ${ }^{68}$ as basic homogeneous catalysts and Amberlyst ${ }^{\circledR}-\mathrm{A} 21,{ }^{10}$ Amberlyst ${ }^{\circledR}-\mathrm{A} 26$ form ${ }^{-} \mathrm{OH}^{68}$ and $\mathrm{K}_{2} \mathrm{CO}_{3(\mathrm{~s})}$, ${ }^{69}$ as solid basic catalysts, in the absence of solvent. Our studies aimed the production of $\beta$-nitroalcohols, symmetric $\beta, \beta$-alkylated1,3-dinitro compounds and allylic nitro compounds. The retrosynthesis proposed for attain these objectives is shown in the Scheme 1. We hypothesized that allylic nitro compounds could be obtained from reaction between the aldehydes 18, 19 and the acetylated $\beta$-nitroalcohols 16, 17 , via a base catalyzed one pot elimination/nitroaldol sequence. The $\beta$-nitroalcohols 16, 17 could be produced via nitroaldol reaction between the nitromethane $(\mathbf{8})$ and the ketones $\mathbf{1}$ and $\mathbf{3}$, respectively, using specific catalytic basic systems, followed by acetylation acid catalyzed. On the other hand, the symmetric $\beta, \beta$-alkylated-1,3-dinitro compounds could be synthesized via a domino nitroaldol reaction/dehydration/Michael reaction process, utilizing suitable catalytic basic conditions.

\section{Results and Discussion}

Thus, based in the retroanalysis proposed (Scheme 1), we started our studies investigating the nitroaldol reaction between the nitroalkanes (8-10) and representative ketones (1-7, 20), employing as homogeneous catalytic system the bases, TBAF. $3 \mathrm{H}_{2} \mathrm{O}$ and DBU, both in tetrahydrofuran (THF). Aiming to employ friendly environmentally conditions, the solid basic catalysts Amberlyst ${ }^{\circledR}-\mathrm{A} 21,{ }^{10}$ Amberlyst ${ }^{\circledR}-\mathrm{A} 26$ form ${ }^{-} \mathrm{OH}^{59}$ and $\mathrm{K}_{2} \mathrm{CO}_{3(\mathrm{~s})}{ }^{69}$, were also experimented in solventless conditions. The results are summarized in Table 1.

Analyzing the Table 1 , it can be observed that nitromethane $\mathbf{8}$ was utilized in stoichiometric amounts in THF, as solvent or in excess (20 equiv.) acting as solventreagent. Thus, the addition of $\mathrm{CH}_{3} \mathrm{NO}_{2}$ to propanone (1)

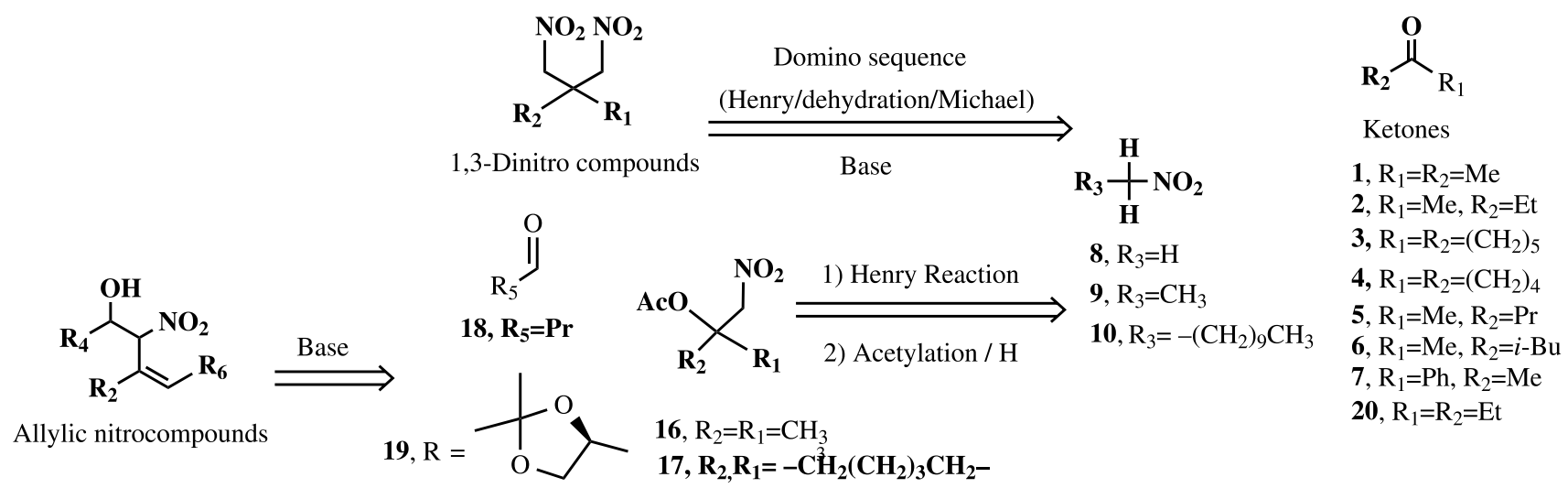

Scheme 1. Retrosynthesis for obtainment of allylic nitro compounds, $\beta, \beta$-alkylated-1,3-dinitro compounds, nitroalcohols and acetylated nitroalcohols. 
Table 1. Reactivity of the ketones 1-7, 20, with the nitroalkanes 8-10, in different homogeneous or heterogeneous basic systems

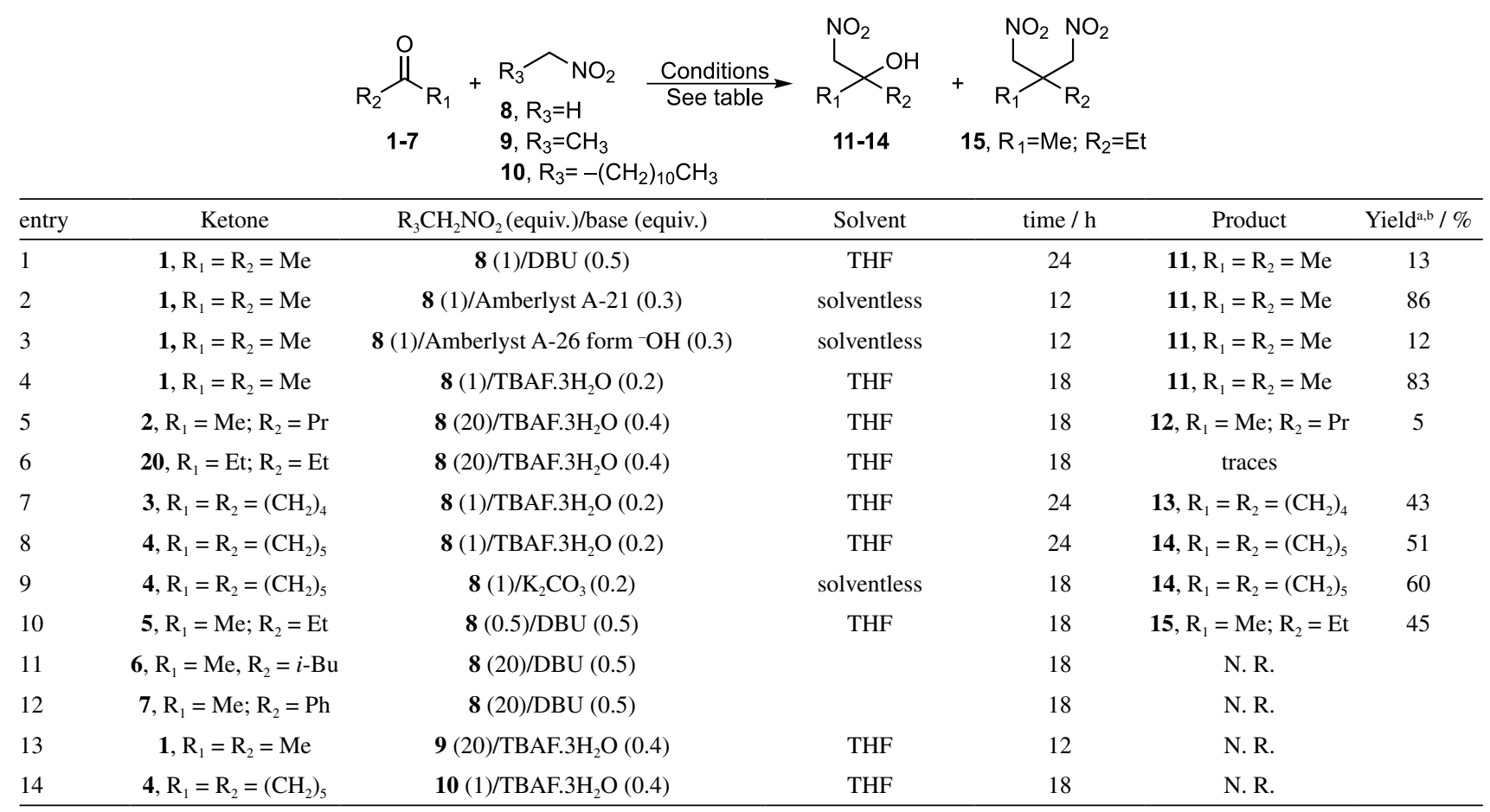

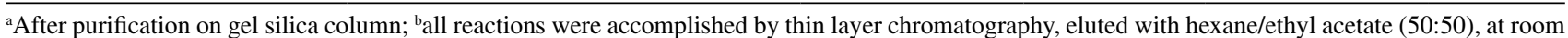
temperature. N. R.: no reaction; THF: tetrahydrofuran; DBU: 1,8-diazabicyclo[5.4.0]undec-7-ene; TBAF. $3 \mathrm{H}_{2} \mathrm{O}$ : tetra- $n$-butylammonium fluoride trihydrate.

to produce 11 showed low yields when DBU 0.5 equiv./ THF or Amberlyst ${ }^{\oplus}$-A26 form ${ }^{-} \mathrm{OH} /$ solventless were employed, as basic systems (entries 1,3). Already the use of Amberlyst ${ }^{\circledR}$-A21 0.3 equiv./solventless, a weak basic resin or TBAF. $3 \mathrm{H}_{2} \mathrm{O}$ ( 0.2 equiv.) furnished very good yields of 11 in multiple grams (entries 2, 4). It is worth mentioning that this reaction exhibited a very low reproducibility, since yields ranging from 5-86\% have been obtained frequently, despite none change in the experimental conditions have been accomplished for us. This behavior is probably due to the difficulty in controlling hydration and consequently the basic strength of these hygroscopic catalysts. This factor interferes with the reversibility of the reaction, especially when low molecular weight ketones are used.

In fact, the use of 2-pentanone (2) in excess of $\mathrm{CH}_{3} \mathrm{NO}_{2}$, in the presence of TBAF. $3 \mathrm{H}_{2} \mathrm{O} 0.4$ equiv. produced the corresponding nitroalcohol 12 with only $5 \%$ yield (entry 5). Likewise, 3-pentanone (20) reacted under the same reaction conditions and no product was formed (entry 6).

On the other hand, cyclic ketones $\mathbf{4}$ and $\mathbf{5}$ reacted with stoichiometric amounts of $\mathrm{CH}_{3} \mathrm{NO}_{2}$ in the presence of TBAF. $3 \mathrm{H}_{2} \mathrm{O} 0.2$ equiv./THF, as a basic catalyst system producing the desired $\mathbf{1 3}$ and $\mathbf{1 4}$ nitroalcohols with 43 and $51 \%$ yields, respectively (entries 7,8 ). Here, it was possible to notice that the use of cyclic ketones led to regular yields with high reaction reproducibility. Probably, the increased in the yield is due to the lower steric impediment inherent to cyclic ketones when compared to acyclic ketones.

The use of $\mathrm{K}_{2} \mathrm{CO}_{3}(0.2)$ /solventless, a basic system more ecologically correct, ${ }^{69}$ easy to handle and low cost provided 14, in $60 \%$ yield (entry 9). The reaction exhibited high reproducibility. It is worth mentioning that propanone (1), 2-pentanone (2) and 3-pentanone (20) did not react when $\mathrm{K}_{2} \mathrm{CO}_{3}$ /solventless or $\mathrm{KF} 1.0$ equiv. $/ i$-PrOH were used, as basic catalysts. Again, this reaction behavior makes evident the high tendency to the reversibility exhibited by low molecular weight aliphatic ketones. Next, butanone (5) was reacted with stoichiometric amounts of nitromethane in presence of 0.5 equivalent DBU/THF aiming the obtainment of corresponding nitroaldol product. However, the $\beta, \beta$-alkylated-1,3-dinitroalkane 15 was obtained in $45 \%$ yield (entry 10 ) without any detection of the product initially expected. The 1,3-dinitroalkane $\mathbf{1 5}$ was formed through a highly reproducible nitroaldol/elimination/addition 1,4 sequence. On the other hand, the more sterically hindered ketone 6 or the less electrophilic ketone 7, when treated with excess $\mathrm{CH}_{3} \mathrm{NO}_{2}$ and DBU 0.5 equiv. or TBAF. $3 \mathrm{H}_{2} \mathrm{O}$ 0.5 equiv. did not react (entries 11 and 12). The use of nitroethane (9) in excess, in the presence of TBAF. $3 \mathrm{H}_{2} \mathrm{O}$ 0.5 equiv./THF or nitrododecane (10) in equal conditions did not lead to any product, making evident the non-reactivity of ketones in the presence of the bulky $\alpha$-substituted 
nitronate anions $\mathrm{s}^{20-23}$ (entries 13, 14). Stimulated by the efficient production of $\beta, \beta$-disubstituted-1,3-nitroalkane 15, under DBU catalysis (Table 1, entry 10), we decided to investigate the addition of nitromethane to ketones $\mathbf{2}, \mathbf{4}$, 5,20 using DBU 0.5 equiv., taking into account the wellknown capacity of DBU to promote elimination reactions efficiently. ${ }^{67}$ The Table 2 summarizes the results obtained. Initially, butanone (5) was reacted in stoichiometric amounts of nitromethane (8) in the absence of solvent, producing 15 in $45 \%$ yield (entry 1 ). The use of 20 equivalents of nitromethane increased the yield to $84 \%$ (entry 2). It is important to mention that the use of other basic catalytic systems, such as TBAF. $3 \mathrm{H}_{2} \mathrm{O}$ ( 0.2 equiv.), Amberlyst ${ }^{\circledR} \mathrm{A} 21$ (0.6 equiv.), Amberlyst ${ }^{\circledR}$ A26 form ${ }^{-} \mathrm{OH}$ ( 0.4 equiv.), $\mathrm{KF} / i$ $\mathrm{PrOH}\left(0.2\right.$ equiv.), $\mathrm{K}_{2} \mathrm{CO}_{3}\left(0.2\right.$ equiv.) and $\mathrm{CH}_{3} \mathrm{NO}_{2}$ in excess (20 equiv.) did not produce 15 . The domino process proved to be highly efficient under DBU catalysis, highlighting the total reproducibility of the reaction. Next, the cyclohexanone (4) was reacted with stoichiometric amounts of $\mathbf{8}$, been formed 21 in 55\% yield (entry 3). The use of excess of $\mathrm{CH}_{3} \mathrm{NO}_{2}$ increased the yield of $\mathbf{2 1}$ to $88 \%$ (entry 4). On the contrary, the use of excess cyclohexanone (20 equiv.) did not lead to the formation of any product (entry 5). As expected, the use of aliphatic ketones 2-pentanone (2) and 3-pentanone (20), provided $\beta, \beta$-disubstituted-1,3-dinitroalkanes 22 and 23, respectively, in low yields. These low yields can be explained by the high reversibility of the acyclic aliphatic ketones 2, 20 (Table 1, entries 5, 6) in the initial nitroaldol reaction that constitutes the domino process.

Analyzing the general reactive behavior of ketones 1-7, 20 in the nitroaldol reaction (Tables 1 and 2) it is evident that there is a high tendency to retro-nitroaldolization and that this behavior is difficult to control, especially when the aliphatic acyclic ketones are used (entries 1-6, Table 1). In fact, when 11 was submitted to acetylation $\left(\mathrm{CH}_{3} \mathrm{CO}\right)_{2} \mathrm{O} /$ $\mathrm{CH}_{2} \mathrm{Cl}_{2}$ /DMAP (4-dimethylaminopyridine) $10 \%$ ) or silanization (TBDMS-Cl (tert-butyldiphenylsilyl chloride)/ $\mathrm{CH}_{2} \mathrm{Cl}_{2}$ /imidazole $10 \%$ or DMAP $10 \%$ ) in basic medium, no product was observed. In practice, there was the formation of retro-nitroaldolization products 8 and $\mathbf{1}$. These could not be isolated, as they are volatile and were lost by evaporation in the reaction workup. In order to confirm the high trend towards reversibility of the reaction, the nitroalcohol $\mathbf{1 1}$ was reacted with chiral $(R)$-glyceraldehyde $\mathbf{1 9}$, easily obtained from D-(+)-mannitol. ${ }^{60}$ The probable nitro alcohol $\mathbf{2 4}$ was not formed. Instead, the $\beta$-nitroalcohol 25 was produced in $60 \%$ yield in an anti:syn ratio, 3.2:1.0 (Scheme 2).

The formation of $\beta$-nitroalcohol $\mathbf{2 5}$ may be occurring in two ways (Scheme 3). The first one consists of a retronitroaldol in 11, followed by a nitroaldol where the methyl nitronate anion would be added to $\mathbf{1 9}$ (way I). The greater electrophilicity of aldehyde $\mathbf{1 9}$ compared to that of

Table 2. Reactivity of $\mathbf{2}, \mathbf{4 , 5}, \mathbf{2 0}$ with $\mathrm{CH}_{3} \mathrm{NO}_{2}$ catalyzed by 0.5 equivalent of DBU aiming to produce $\beta, \beta$-disubstituted-1,3-dinitroalkanes

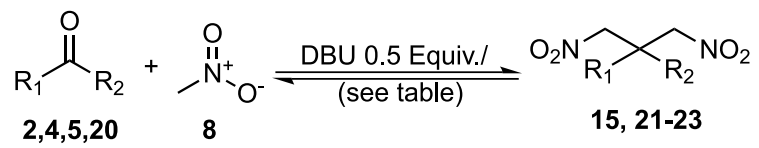

\begin{tabular}{|c|c|c|c|c|c|}
\hline entry & Ketone (1.0 equiv.) & Solvent & $\mathrm{CH}_{3} \mathrm{NO}_{2}(\mathbf{8}) /$ equiv. & 1,3-Dinitro compound & Yield $\mathrm{a}, \mathrm{b} / \%$ \\
\hline 1 & $\mathbf{5}, \mathrm{R}_{1}=\mathrm{Me} ; \mathrm{R}_{2}=\mathrm{Et}$ & - & -2.0 & $\mathbf{1 5}, \mathrm{R}_{1}=\mathrm{Me} ; \mathrm{R}_{2}=\mathrm{Et}$ & 45 \\
\hline 2 & $\mathbf{5}, \mathrm{R}_{1}=\mathrm{Me} ; \mathrm{R}_{2}=\mathrm{Et}$ & - & 20 & $\mathbf{1 5}, \mathrm{R}_{1}=\mathrm{Me} ; \mathrm{R}_{2}=\mathrm{Et}$ & 84 \\
\hline 3 & $\mathbf{4}, \mathrm{R}_{1}=\mathrm{R}_{2}=\left(\mathrm{CH}_{2}\right)_{5}$ & - & 2.0 & 21, $\mathrm{R}_{1}=\mathrm{R}_{2}=\left(\mathrm{CH}_{2}\right)_{5}$ & 55 \\
\hline 4 & $\mathbf{4}, \mathrm{R}_{1}=\mathrm{R}_{2}=\left(\mathrm{CH}_{2}\right)_{5}$ & - & 20 & 21, $\mathrm{R}_{1}=\mathrm{R}_{2}=\left(\mathrm{CH}_{2}\right)_{5}$ & 88 \\
\hline 5 & $\mathbf{4}, \mathrm{R}_{1}=\mathrm{R}_{2}=\left(\mathrm{CH}_{2}\right)_{5}$ & 4 (20 equiv.) & 1.0 & no reaction & \\
\hline 6 & $\mathbf{2}, \mathrm{R}_{1}=\mathrm{Me}, \mathrm{R}_{2}=\operatorname{Pr}$ & - & 20 & 22, $\mathrm{R}_{1}=\mathrm{Me} ; \mathrm{R}_{2}=\operatorname{Pr}$ & 30 \\
\hline 7 & $\mathbf{2 0}, \mathrm{R}_{1}=\mathrm{Et}, \mathrm{R}_{2}=\mathrm{Et}$ & - & 20 & $\mathbf{2 3}, \mathrm{R}_{1}=\mathrm{R}_{2}=\mathrm{Et}$ & 15 \\
\hline
\end{tabular}

${ }^{a}$ After purification on silica gel column; ball reactions were accomplished by thin layer chromatography, eluted with hexane/ethyl acetate (50:50), at room temperature by $18 \mathrm{~h}$.
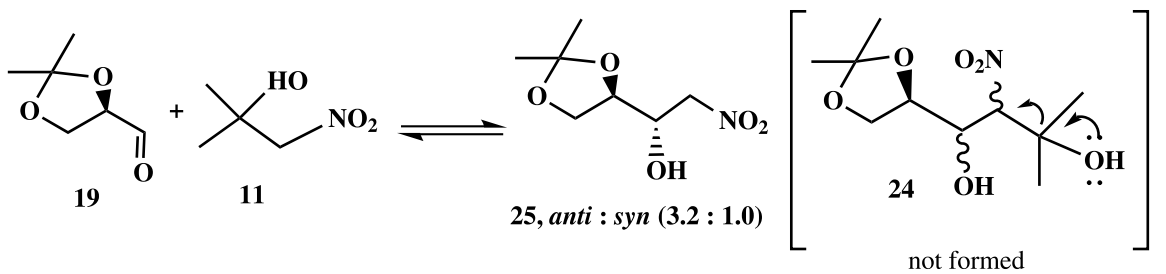

Scheme 2. Reaction of $\mathbf{1 1}$ with $\mathbf{1 9}$ producing $\mathbf{2 5}$. 
propanone could favor the way I. This way is reinforced since the anti:syn ratio (3.2:1.0) obtained is similar to that observed when the methyl nitronate anion was added separately to 19 , under the same conditions of reaction. ${ }^{60} \mathrm{On}$ the other hand, the addition of $\beta$-nitroalcohol 11 to 19 via way II, would be more difficult to happen due to the greater stereo volume of $\mathbf{1 1}$. If $\mathbf{2 4}$ was produced, a subsequent retro-nitroaldol in $\mathbf{2 4}$ would lead to $\mathbf{2 5}$.

Our results others ${ }^{24-29}$ have shown that the reaction of nitroaldol with ketones often requires a fine-tuning of experimental conditions for the reproducibility of the reaction, which is very difficult to achieve. Thus, the use of basic catalysts, such as Amberlyst ${ }^{\circledR} \mathrm{A} 21$ resin or TBAF. $3 \mathrm{H}_{2} \mathrm{O}$, both hygroscopic, can easily change the basic force through the absorption of water making the yield of 11 vary from 12 to $86 \%$ (entries 2-4; Table 1).
Considering the high tendency of acetylated $\beta$-nitroalcohols to undergo elimination in basic media, we investigate a new route for obtainment of synthetically versatile allylic nitro compounds (Scheme 4).

Thus, acetylation of $\mathbf{1 1}$ and $\mathbf{2 6}$ was performed efficiently using $\mathrm{Ac}_{2} \mathrm{O}$ in catalytic amounts of $70 \% \mathrm{HClO}_{4}$ for $1 \mathrm{~h}$, at room temperature, furnishing 16 and $\mathbf{1 7}$ in $90 \%$ yield. The acidic medium completely inhibited the retro-nitroaldol reaction. Next, 16 and $\mathbf{1 7}$ were reacted with aldehydes 18 and $\mathbf{1 9}$, respectively to produce, in a single flask, the allylic nitro compounds $\mathbf{2 7}$ and 28, via an elimination/nitroaldol reaction, in an overall yield of 72 and $63 \%$, respectively. The rapid formation of allylic nitro compounds 27 or 28 can be rationalized through the mechanistic scheme proposed (Scheme 5).

The base (TBAF or DBU) reacted faster with acetylated<smiles>CC1(C)OC[C@H](C=O)O1</smiles>

19

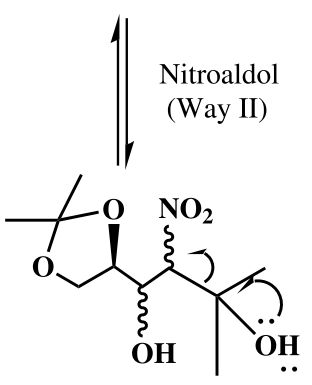

24

11<smiles>CC(C)(O)C[N+](=O)[O-]</smiles>

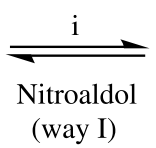<smiles>CC(C)=O</smiles><smiles>[R4][C@H]1C=C[C@@H]1C(C)=O</smiles>

Retronitroaldo

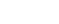

$$
x^{2}
$$

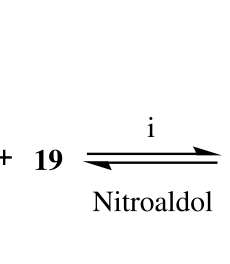

Nitroaldol<smiles>CC(=O)[O+][C@@H](O)[C@@H]1COC(C)(C)O1</smiles>

(3.2:1.0)
Scheme 3. Mechanistic rationalization to formation of $\mathbf{2 5}$.<smiles>CC(C)(O)C[N+](=O)[O-]</smiles>

11

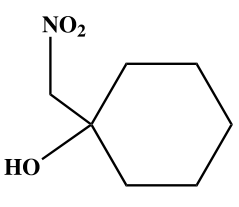

26
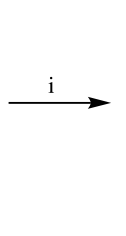<smiles>CC(C)(C[N+](=O)[O-])O[Na]</smiles>

16<smiles>CC1(C)OC[C@H](C=O)O1</smiles>

18<smiles>C=C(C)C(O)C(O)[C@H]1COC(C)(C)O1</smiles>

25, anti : syn

(3.2:1.0)

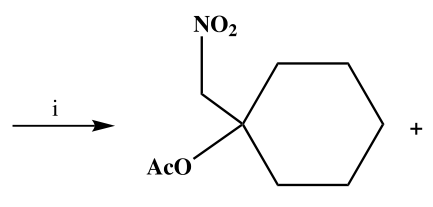

17<smiles>CC#CC</smiles>

19<smiles>CCC[C@H](O)[C@@H](O)C1=CCCCC1</smiles>

i) $\mathrm{Ac}_{2} \mathrm{O} / \mathrm{HClO}_{4} 70 \%$ cat./rt $(90 \%)$

ii) DBU 0.5 equiv., THF, rt, $4 \mathrm{~h},(80 \%)$, diastereomeric ratio $(7.1: 7.3: 1.0)$

iii) TBAF. $3 \mathrm{H}_{2} \mathrm{O} 0.2$ equiv., THF, rt, $4 \mathrm{~h},(70 \%)$, anti:syn (1.0 : 7.0)

Scheme 4. Synthesis of the allylic nitro compounds 27,28 from 11, 26. 

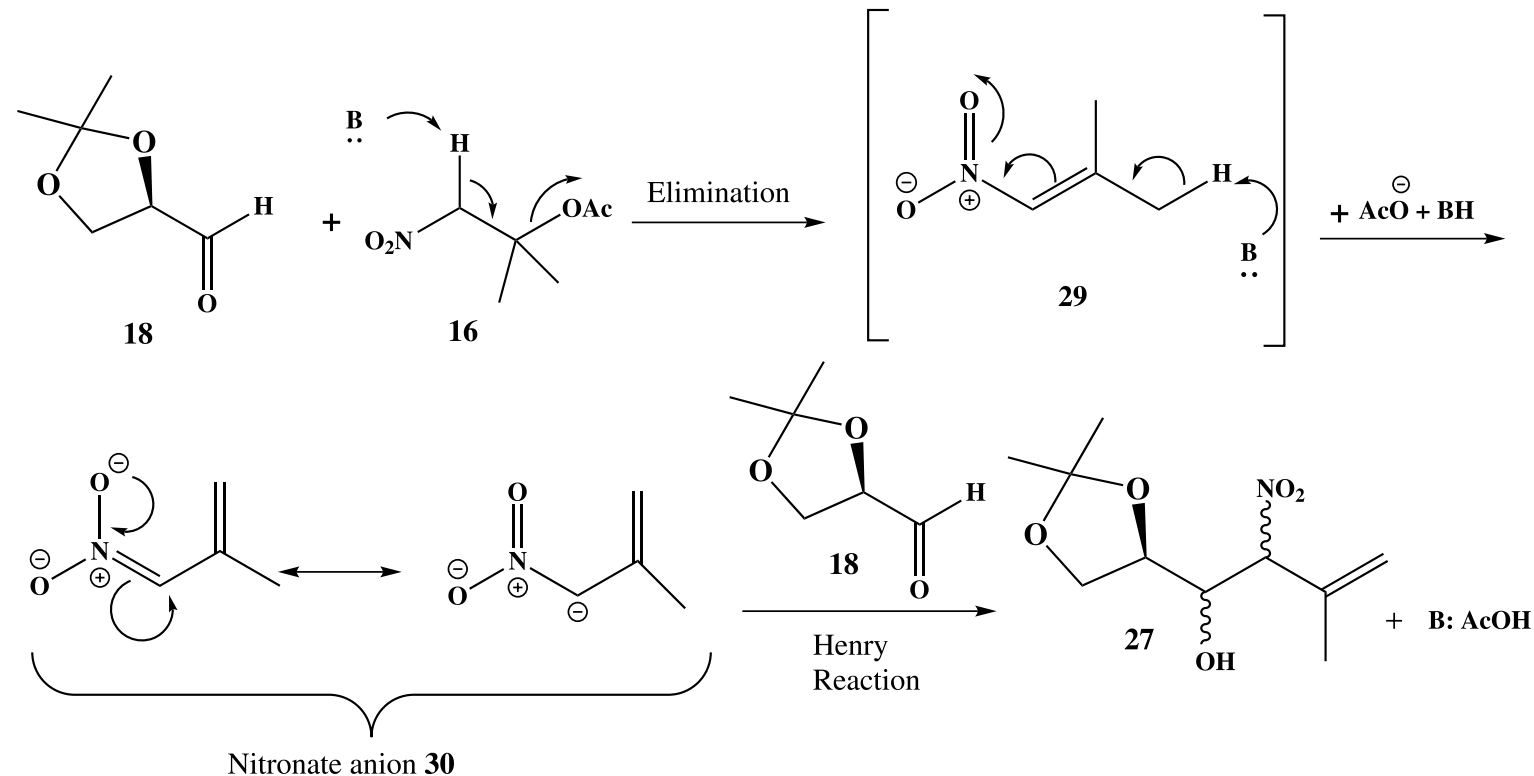

Scheme 5. Mechanistic scheme propose for obtainment of the allylic nitro compound $\mathbf{2 7}$ from $\mathbf{1 8 .}$

nitro alcohol 16, leading to ready elimination of acetate group, producing the trisubstituted nitroalkene intermediate 29. This is deprotonated in the allylic position generating the very stable nitronate anion $\mathbf{3 0}$ that add to the reactive aldehyde $\mathbf{1 8}$ leading to allylic nitro compound $\mathbf{2 7}$. The high tendency to elimination of the $\beta$-acetylated nitro alcohols 16, 17 was determinant to the obtainment of this class of compounds. The mechanism proposed could be supported from observation of a rapid and total production of the intermediate 29, (as well as the analogous originated from 17), when 16 and $\mathbf{1 7}$ were individually placed to react in the same basic conditions used in the production of $\mathbf{2 7}$ and $\mathbf{2 8}$. It is worth mentioned that both TBAF and DBU promoted the formation of the allylic nitro compounds $\mathbf{2 7}$ and $\mathbf{2 8}$.

\section{Conclusions}

Our results have shown that the $\beta$-nitroaldol reaction with low molecular weight ketone often requires a fine adjustment in the reaction conditions in order to reproduce useful yields. Cyclic ketones exhibited moderated yield and high reaction reproducibility, when catalyzed by Amberlyst ${ }^{\circledR} \mathrm{A} 21, \mathrm{~K}_{2} \mathrm{CO}_{3(\mathrm{~s})}$, or TBAF. $3 \mathrm{H}_{2} \mathrm{O}$ in stoichiometric amount of $\mathrm{CH}_{3} \mathrm{NO}_{2}$. On the other hand, after several screenings with several basic catalytic systems, DBU $50 \% / \mathrm{rt} / 18 \mathrm{~h} /$ using excess $\mathrm{CH}_{3} \mathrm{NO}_{2}$ (20 equiv.), proved to be an efficient basic system for the production of $\beta, \beta$-disubstituted-1,3-dinitroalkanes 15, 21-23, through of domino nitroaldol/elimination/1,4-addition sequence. In addition, a new and efficient route was developed to access synthetically versatile allylic nitro compounds $\mathbf{2 7}$, 28 in 63 and $72 \%$ global yield, respectively. A mechanism that involves nitroaldol reaction/elimination sequence has been proposed.

\section{Experimental}

\section{General information}

TBAF. $3 \mathrm{H}_{2} \mathrm{O}$ solid, $\mathrm{K}_{2} \mathrm{CO}_{3}$, nitromethane, Amberlyst ${ }^{\circledR}$ A21 and Amberlyst ${ }^{\circledast}$ A26 form ${ }^{-} \mathrm{OH}$ were commercially available from Sigma-Aldrich, ${ }^{\circledR}$ (St. Louis, USA), and were used as purchased. THF was dried according to a literature procedure. ${ }^{66}{ }^{1} \mathrm{H}$ and ${ }^{13} \mathrm{C}$ nuclear magnetic resonance (NMR) spectra were recorded on a Varian or Bruker spectrometer operating at $(200,400$ or $500 \mathrm{MHz})$ and $(50,100$ or $125 \mathrm{MHz}$ ), at $25^{\circ} \mathrm{C}$ by using $\mathrm{CDCl}_{3} 0.5 \%$ tetramethylsilane (TMS) v/v as solvent. Chemical shifts $(\delta)$ are reported in ppm and the coupling constant $(J)$ is in hertz $(\mathrm{Hz})$. The analyses by gas chromatography (GC)-mass was realized on Shimadzu GC/MS-QP 5000.

Synthesis of nitro alcohols 11, 13, 14-typical procedure

\section{2-Methyl-1-nitropropan-2-ol (11), TBAF. $3 \mathrm{H}_{2} \mathrm{O}$, as base}

To a round bottom flask was added a solution of TBAF. $3 \mathrm{H}_{2} \mathrm{O}(2.57 \mathrm{~g}, 8.17 \mathrm{mmol})$, in THF anhydrous ${ }^{66}$ $(6.0 \mathrm{~mL})$ followed by nitromethane $(2.19 \mathrm{~mL}, 40.86 \mathrm{mmol})$. The reaction mixture was maintained under stirring for $30 \mathrm{~min}$, at room temperature. Next, propanone (1) $3 \mathrm{~mL}$, $2.36 \mathrm{~g}, 40.86 \mathrm{mmol}$ ) was added and the mixture stirred over night at room temperature. The $\beta$-nitroalcohol 11 was isolated by direct filtration over a silica gel chromatograph column washed with hexane/EtOAc (80:20). The volatiles 
were evaporated under reduced pressure to furnish $4.02 \mathrm{~g}$ (83\% yield) of 11, as a fluid colorless liquid in high purity. ${ }^{1} \mathrm{H} \mathrm{NMR}\left(400 \mathrm{MHz}, \mathrm{CDCl}_{3}\right.$ ) $\delta 1.37$ (s, 6H), 3.14 (s, 1H, $\mathrm{OH}), 4.45(\mathrm{~s}, 2 \mathrm{H})$.

2-Methyl-1-nitropropan-2-ol (11), Amberlyst ${ }^{\circledR} A-21$, as base

To a round bottom flask was added $\mathrm{CH}_{3} \mathrm{NO}_{2}(1.1 \mathrm{~mL}$, $20.43 \mathrm{mmol})$, Amberlyst A-2 $1^{\circledR}$ resin $(3 \mathrm{~mL})$, followed by propanone (1) $(1.5 \mathrm{~mL}, 1.18 \mathrm{~g}, 20.43 \mathrm{mmol})$. The reaction medium was left to react for $18 \mathrm{~h}$, at room temperature, in the absence of stirring. After this time, the reaction medium was filtered through a simple funnel covered with filter paper and the filtered evaporated under reduced pressure to furnish $3.87 \mathrm{~g}(80 \%)$ of the desired nitroalcohol 11, as a fluid colorless liquid in high purity.

1-(Nitromethyl)cyclohexan-1-ol (14), $\mathrm{K}_{2} \mathrm{CO}_{3}$ as base

To a round bottom flask was added a solution of $\mathrm{K}_{2} \mathrm{CO}_{3}(0.208 \mathrm{~g}, 0.8 \mathrm{mmol})$, followed by $0.22 \mathrm{~mL}$ of nitromethane $(0.244 \mathrm{~g}, 4 \mathrm{mmol})$. This mixture was maintained under stirring for $30 \mathrm{~min}$, at room temperature. Next, cyclohexanone (4) $(0.42 \mathrm{~mL}, 81.72 \mathrm{mmol})$ was added and the mixture stirred at room temperature for $18 \mathrm{~h}$. The reaction evolution was monitored by thin layer chromatography, eluted with hexane/ethyl acetate (50:50). The reaction medium was submitted to filtration over a silica gel column chromatograph washed with dichloromethane. After evaporation of the volatile liquid at reduced pressure, it was obtained $0.308 \mathrm{~g}$ ( $60 \%$ yield) of the $\beta$-nitroalcohol $\mathbf{1 4}$, as a fluid colorless liquid in high purity.

Spectral data for 1-(nitromethyl)cyclohexan-1-ol (14)

${ }^{1} \mathrm{H} \mathrm{NMR}\left(400 \mathrm{MHz}, \mathrm{CDCl}_{3}\right) \delta 1.26(\mathrm{~m}, 2 \mathrm{H}), 1.46(\mathrm{~m}$, $4 \mathrm{H}), 1.79(\mathrm{~m}, 4 \mathrm{H}), 2.26(\mathrm{t}, 1 \mathrm{H}, J 4.0 \mathrm{~Hz}), 4.38(\mathrm{~s}, 2 \mathrm{H})$; ${ }^{13} \mathrm{C} \mathrm{NMR}\left(100 \mathrm{MHz}, \mathrm{CDCl}_{3}\right) \delta 21.43\left(\mathrm{CH}_{2}\right), 25.15\left(2 \mathrm{CH}_{2}\right)$, $34.91\left(2 \mathrm{CH}_{2}\right), 70.77(\mathrm{C}), 84.80\left(\mathrm{CH}_{2}\right)$.

Spectral data for 1-(nitromethyl)cyclopentan-1-ol (13)

${ }^{13} \mathrm{C} \mathrm{NMR}\left(100 \mathrm{MHz}, \mathrm{CDCl}_{3}\right) \delta 23.61\left(2 \mathrm{CH}_{2}\right), 37.95$ $\left(2 \mathrm{CH}_{2}\right), 80.14(\mathrm{C}), 83.56\left(\mathrm{CH}_{2}\right)$.

Synthesis of $\beta, \beta$-disubstituted-1,3-dinitroalkanes 15, 21-23-typical procedure

\section{2-Methyl-1-nitro-2-(nitromethyl)butane (15)}

To a round bottom flask under magnetic stirring and at room temperature was added nitromethane (1.22 g, $20 \mathrm{mmol}$ ) and $75 \mu \mathrm{L} \mathrm{DBU}(76.12 \mathrm{mg}, 0.5 \mathrm{mmol})$ and the reaction mixture was maintained stirring for $10 \mathrm{~min}$. Next, butanone 2 ( $71 \mathrm{mg}, 74.5 \mu \mathrm{L}, 1 \mathrm{mmol}$ ) was added and the reaction medium remained under stirring by $18 \mathrm{~h}$. After this time, the reaction crude was purified by filtration in a silica gel column eluted twice with $50 \mathrm{~mL}$ hexane:ethyl acetate (70:30). The solvents were evaporated to produce $147 \mathrm{mg}$ $(80 \%)$ of $\mathbf{1 5}$, as a viscous yellow liquid.

${ }^{1} \mathrm{H}$ NMR (400 MHz, $\left.\mathrm{CDCl}_{3}\right) \delta 1.00(\mathrm{t}, 3 \mathrm{H}, J 4.0 \mathrm{~Hz})$, 1.17 (s, 3H), 1.56 (q, 2H, J 4.0 Hz), 4.60 (q, 4H, J4.0 Hz); ${ }^{13} \mathrm{C} \mathrm{NMR}\left(100 \mathrm{MHz}, \mathrm{CDCl}_{3}\right) \delta 7.32\left(\mathrm{CH}_{3}\right), 19.94\left(\mathrm{CH}_{3}\right)$, $28.54\left(\mathrm{CH}_{2}\right), 38.62(\mathrm{C}), 79.84\left(\mathrm{~s}, 2 \mathrm{CH}_{2}\right) ;{ }^{13} \mathrm{C}$ attached proton test (APT) NMR (100 MHz, $\left.\mathrm{CDCl}_{3}\right) \delta 7.32\left(\mathrm{CH}_{3}\right), 19.95$ $\left(\mathrm{CH}_{3}\right), 28.54\left(\mathrm{CH}_{2}\right), 38.62(\mathrm{C}), 79.84\left(2 \mathrm{CH}_{2}\right)$.

Spectral data for 1,1-bis(nitromethyl)cyclohexane (21)

${ }^{1} \mathrm{H}$ NMR (500 MHz, $\left.\mathrm{CDCl}_{3}\right) \delta 1.57(\mathrm{~m}, 10 \mathrm{H}), 4.69$ (s, $4 \mathrm{H}) ;{ }^{13} \mathrm{C} \mathrm{NMR}\left(125 \mathrm{MHz}, \mathrm{CDCl}_{3}\right) \delta 20.75\left(2 \mathrm{CH}_{2}\right), 24.95$ $\left(\mathrm{CH}_{2}\right), 31.25\left(\mathrm{CH}_{2}\right), 38.41(\mathrm{C}), 78.95\left(2 \mathrm{CH}_{2}\right)$.

Spectral data for 2-methyl-1-nitro-2-(nitromethyl)pentane (22)

${ }^{1} \mathrm{H}$ NMR (400 MHz, $\left.\mathrm{CDCl}_{3}\right) \delta 0.94(\mathrm{t}, 3 \mathrm{H}, J 4.0 \mathrm{~Hz})$, $1.16(\mathrm{~s}, 3 \mathrm{H}), 1.42(\mathrm{~m}, 4 \mathrm{H}) 4.59(\mathrm{q}, 4 \mathrm{H}, J 6.0 \mathrm{~Hz}) ;{ }^{13} \mathrm{C} \mathrm{NMR}$ $\left(100 \mathrm{MHz}, \mathrm{CDCl}_{3}\right) \delta 14.27\left(\mathrm{CH}_{3}\right), 16.36\left(\mathrm{CH}_{2}\right), 20.63$ $\left(\mathrm{CH}_{3}\right), 38.07\left(\mathrm{CH}_{2}\right), 38.56(\mathrm{C}), 80.12\left(\mathrm{CH}_{2}\right) ;{ }^{13} \mathrm{C}$ APT NMR $\left(100 \mathrm{MHz}, \mathrm{CDCl}_{3}\right) \delta 14.26\left(\mathrm{CH}_{3}\right), 16.36\left(\mathrm{CH}_{2}\right), 20.63$ $\left(\mathrm{CH}_{3}\right), 38.07\left(\mathrm{CH}_{2}\right), 38.56(\mathrm{C}), 80.12\left(\mathrm{CH}_{2}\right)$.

Spectral data for 3,3-bis(nitromethyl)pentane (23)

${ }^{1} \mathrm{H} \mathrm{NMR}\left(400 \mathrm{MHz}, \mathrm{CDCl}_{3}\right) \delta 0.92(\mathrm{t}, 6 \mathrm{H}, J 4.0 \mathrm{~Hz})$, 1.57 (q, 4H, J 4.0 Hz), $4.58(\mathrm{~m}, 2 \mathrm{H}) ;{ }^{13} \mathrm{C} \mathrm{NMR}(100 \mathrm{MHz}$, $\left.\mathrm{CDCl}_{3}\right) \delta 7.61\left(2 \mathrm{CH}_{3}\right), 28.99\left(2 \mathrm{CH}_{2}\right), 74.14(\mathrm{C}), 82.24$ $\left(2 \mathrm{CH}_{2}\right) ;{ }^{13} \mathrm{C}$ APT NMR $\left(100 \mathrm{MHz}, \mathrm{CDCl}_{3}\right) \delta 7.61\left(2 \mathrm{CH}_{3}\right)$, $28.99\left(2 \mathrm{CH}_{2}\right), 74.14(\mathrm{C}), 82.23\left(2 \mathrm{CH}_{2}\right)$.

Synthesis of the $\beta$-nitroacetates 16,17-typical procedure

\section{1-(Nitromethyl)cyclohexyl acetate (17)}

To a round bottom flask under magnetic stirring and at room temperature was added the $\beta$-nitroalcohol 26 (3.35 g; $21.1 \mathrm{mmol}), 20 \mathrm{~mL}$ of acetic anhydride and $\mathrm{HClO}_{4} 70 \%(120 \mu \mathrm{L})$. After $1 \mathrm{~h}$, to the reaction medium was added $30 \mathrm{~mL} \mathrm{H}_{2} \mathrm{O}$ and effected the extraction with dichloromethane $(2 \times 30 \mathrm{~mL})$. The reunited organic phases were washed with saturated sodium bicarbonate $(2 \times 30 \mathrm{~mL})$, dried over $\mathrm{Na}_{2} \mathrm{SO}_{4}$ and evaporated under reduced pressure. The residue obtained was purified by column chromatography on silica gel and eluted with hexane/ethyl acetate (70:30). It was obtained $3.8 \mathrm{~g}$ (90\% yield) of nitroester 17, as a pale-yellow liquid.

${ }^{1} \mathrm{H}$ NMR (500 MHz, $\left.\mathrm{CDCl}_{3}\right) \delta 0.89(\mathrm{~m}, 2 \mathrm{H}), 1.33(\mathrm{~m}$, 4H), 1.57 (m, 4H), 2.09 (s, 3H), $4.95(\mathrm{~s}, 2 \mathrm{H}) ;{ }^{13} \mathrm{C} \mathrm{NMR}$ $\left(125 \mathrm{MHz}, \mathrm{CDCl}_{3}\right) \delta 21.12\left(\mathrm{CH}_{2}\right), 22.35\left(\mathrm{CH}_{3}\right), 24.85$ $\left(\mathrm{CH}_{2}\right), 32.60\left(\mathrm{CH}_{2}\right), 79.41\left(\mathrm{CH}_{2}\right), 82.74(\mathrm{C}), 170.67(\mathrm{C})$. 
Spectral data for 2-methyl-1-nitropropan-2-yl acetate (16)

${ }^{1} \mathrm{H}$ NMR (400 MHz, $\mathrm{CDCl}_{3}$ ) $\delta 1.57$ (s, 6H), 2.04 (s, $3 \mathrm{H}), 4.85(\mathrm{~s}, 2 \mathrm{H}) ;{ }^{13} \mathrm{C} \mathrm{NMR}\left(100 \mathrm{MHz}, \mathrm{CDCl}_{3}\right) \delta 21.98$ $\left(\mathrm{CH}_{3}\right), 24.76\left(2 \mathrm{CH}_{3}\right), 77.73(\mathrm{C}), 80.80\left(\mathrm{CH}_{2}\right), 170.46(\mathrm{C})$.

Synthesis of the allylic nitro compounds 27, 28-typical procedure

1-((R)-2,2-Dimethyl-1,3-dioxolan-4-yl)-3-methyl-2-nitrobut3-en-1-ol (27), DBU as base

To a round bottom flask contained a solution of $\mathbf{1 6}$ $(0.50 \mathrm{~g}, 3.85 \mathrm{mmol})$ in THF $(3 \mathrm{~mL})$, under magnetic stirring and at room temperature, was added a solution of chiral aldehyde 18 (0.62 g; $3.85 \mathrm{mmol})$ in THF ( $3 \mathrm{~mL})$ and DBU $(0.29 \mathrm{~g}, 1.92 \mathrm{mmol}, 0.5$ equivalent). The reaction mixture was maintained stirring for $3 \mathrm{~h}$. After this time, the THF was evaporated at reduced pressure and the remaining viscous orange liquid was purified by silica gel column chromatography, eluted with hexane:AcOEt solution (85:15), furnishing $0.71 \mathrm{~g}$ of 27 (80\% yield), as a pale yellow oil constituted by a mixture of three diastereoisomers (7.1:7.0:1.0; measured by $\left.{ }^{13} \mathrm{C} \mathrm{NMR}\right)$.

${ }^{1} \mathrm{H}$ NMR $\left(200 \mathrm{MHz}, \mathrm{CDCl}_{3}\right) \delta 1.48-1.3(\mathrm{~m}, 6 \mathrm{H}), 1.91$ $(\mathrm{m}, 3 \mathrm{H}), 2.06(\mathrm{~d}, 1 \mathrm{H}, J 9.5 \mathrm{~Hz}, \mathrm{OH}), 3.03(\mathrm{~d}, 1 \mathrm{H}, J 5.8 \mathrm{~Hz}$, $\mathrm{OH}), 3.08(\mathrm{~d}, 1 \mathrm{H}, J 3.8 \mathrm{~Hz}, \mathrm{OH}), 4.17-3.89(\mathrm{~m}, 2 \mathrm{H}), 4.3-$ $4.42(\mathrm{~m}, 1 \mathrm{H}), 4.99(\mathrm{~d}, 2 \mathrm{H}, J 7.7 \mathrm{~Hz}), 5.38-5.21(\mathrm{~m}, 2 \mathrm{H})$; ${ }^{13} \mathrm{C} \mathrm{NMR}\left(50 \mathrm{MHz}, \mathrm{CDCl}_{3}\right.$ ) (spectral data for major isomer) d $18.99\left(\mathrm{CH}_{3}\right), 24.97\left(\mathrm{CH}_{3}\right), 26.27\left(\mathrm{CH}_{3}\right), 66.78\left(\mathrm{CH}_{2}\right)$, $70.23(\mathrm{CH}), 74.89(\mathrm{CH}), 93.65(\mathrm{CH}), 109.63(\mathrm{C}), 121.31$ $\left(\mathrm{CH}_{2}\right), 136.02$ (C); GC-MS (70 eV) $\mathrm{m} / z,(\%)$ 55, 59, 73, 84, 101 (100), 115, 131, 185, 216, 115, 101, 73, 59.

\section{1-(Cyclohex-1-en-1-yl)-1-nitropentan-2-ol (28), TBAF. $3 \mathrm{H}_{2} \mathrm{O}$} as base

To a round bottom flask contained 17 ( $0.28 \mathrm{~g}$; $1.42 \mathrm{mmol}$ ) was added, under magnetic stirring and at room temperature, $5 \mathrm{~mL}$ of a solution of TBAF. $3 \mathrm{H}_{2} \mathrm{O}$ $(0.062 \mathrm{~g}, 0.236 \mathrm{mmol})$ in THF. After $30 \mathrm{~min} 0.085 \mathrm{~g}$ $(1.18 \mathrm{mmol})$ of butyraldehyde 19 dissolved in $2 \mathrm{~mL}$ of THF was added and the reaction stirred overnight. Next, the reaction crude was purified by filtration on a silica gel chromatograph column eluted twice with $40 \mathrm{~mL}$ of hexane:ethyl acetate (70:30). The reunited volatiles were evaporated at reduced pressure to produce $0.208 \mathrm{~g}(70 \%)$ of the alyllic nitro compound (+/-)-28 (diastereomeric ratio anti:syn; 7:1), as a viscous yellow liquid.

${ }^{1} \mathrm{H}$ NMR $\left(500 \mathrm{MHz}, \mathrm{CDCl}_{3}\right.$ ) (spectral data for major isomer) $\delta 0.94(\mathrm{t}, 3 \mathrm{H}, J 4.0 \mathrm{~Hz}), 2.1-1.25(\mathrm{~m}, 12 \mathrm{H}), 2.48$ (s, 1H), $4.32(\mathrm{~m}, 1 \mathrm{H}), 4.72(\mathrm{~d}, 1 \mathrm{H}, J 6.0 \mathrm{~Hz}), 6.00$ (bs, 1H); ${ }^{13} \mathrm{C}$ NMR $\left(125 \mathrm{MHz}, \mathrm{CDCl}_{3}\right) \delta 13.80\left(\mathrm{CH}_{3}\right), 18.34$ $\left(\mathrm{CH}_{2}\right), 21.59\left(\mathrm{CH}_{2}\right), 22.23\left(\mathrm{CH}_{2}\right), 24.58\left(\mathrm{CH}_{2}\right), 25.38\left(\mathrm{CH}_{2}\right)$,
$34.20\left(\mathrm{CH}_{2}\right), 69.63(\mathrm{CH}), 99.38(\mathrm{CH}), 130.27(\mathrm{C}), 133.05$ $(\mathrm{CH}) ;{ }^{13} \mathrm{C}$ APT NMR $\left(125 \mathrm{MHz}, \mathrm{CDCl}_{3}\right) \delta 13.80\left(\mathrm{CH}_{3}\right)$, $18.34\left(\mathrm{CH}_{2}\right), 21.59\left(\mathrm{CH}_{2}\right), 22.23\left(\mathrm{CH}_{2}\right), 24.58\left(\mathrm{CH}_{2}\right), 25.38$ $\left(\mathrm{CH}_{2}\right), 34.20\left(\mathrm{CH}_{2}\right), 69.63(\mathrm{CH}), 99.38(\mathrm{CH}), 130.27(\mathrm{C})$, $133.05(\mathrm{CH})$.

\section{Supplementary Information}

Supplementary data are available free of charge at http://jbcs.sbq.org.br as PDF file.

\section{Acknowledgments}

We thank CAPES and CNPq for the fellowship for some authors.

\section{References}

1. Seebach, D.; Colvin, E. W.; Leher, F.; Weller, T.; Chimia 1979, 33,1 .

2. Seebach, D.; Beck, A. K.; Mukhopadhyay, T.; Thomas, E.; Helv. Chim. Acta 1982, 65, 1101.

3. Rosini, G.; Ballini, R.; Synthesis 1988, 833.

4. Rosini, G. In Comprehensive Organic Synthesis, vol. 2.; Trost, B. M.; Fleming, I., eds; Pergamon Press: Oxford, England (United Kingdom), 1992, p. 321.

5. Shvekhgeimer, M.-G. A.; Russ. Chem. Rev. 1998, 67, 35.

6. Ono, N.; The Nitro Group in Organic Synthesis; Wiley-VCH: New York, United States of America, 2001.

7. Henry, L.; C. R. Hebd. Seances Acad. Sci. 1895, 120, 1265.

8. Henry, L.; Bull. Soc. Chim. Fr. 1985, 13, 999.

9. Ballini, R.; Bosica, G.; J. Org. Chem. 1997, 62, 425.

10. Luzzio, F. A.; Tetrahedron 2001, 57, 915.

11. Akutu, K.; Kabashima, H.; Seki, T.; Hattori, H.; Appl. Catal., A 2003, 247, 65.

12. Palomo, C.; Oiarbide, M.; Mielgo, A.; Angew. Chem., Int. Ed. 2004, 43, 5442.

13. Boruwa, J.; Gogoi, N.; Saikia, P. P.; Barua, N. C.; Tetrahedron: Asymmetry 2006, 17, 3315.

14. Palomo, C.; Oiarbide, M.; Laso, A.; Eur. J. Org. Chem. 2007, 17, 2561 .

15. Alizadeh, A.; Khodaei, M. M.; Abdi, G.; Kordestani, D.; Bull. Korean Chem. Soc. 2012, 33, 3640.

16. Zhang, S.; Li, Y.; Xu, Y.; Wang, Z.; Chin. Chem. Lett. 2018, 29 , 873.

17. Sappino, C.; Primitivo, L.; de Angelis, M.; Domenici, M. O.; Mastrodonato, A.; Romdan, I. B.; Tatangelo, C.; Suber, L.; Pilloni, L.; Ricelli, A.; Righi, G.; ACS Omega 2019, 4, 21809.

18. Dong, L.; Chen, F.-E.; RSC Adv. 2020, 10, 2313.

19. Singh, N.; Pandey, J.; Mini-Rev. Org. Chem. 2020, 17, 297.

20. Gaggero, N.; Eur. J. Org. Chem. 2019, 47, 7613. 
21. Otevrel, J.; Svestka, D.; Bobal, P.; Org. Biomol. Chem. 2019, $17,5244$.

22. Chalotra, N.; Sultan, S.; Shah, B. A.; Asian J. Org. Chem. 2020, 9, 863.

23. Sadhukhan, S.; Santhi, J.; Baire, B.; Chem. - Eur. J. 2020, 26, 7145.

24. Fraser, H. B.; Kon, G. A. R.; J. Chem. Soc. 1934, 604.

25. Lambert, A.; Lowe, A.; J. Chem. Soc. 1947, 243, 1517.

26. Buehler, C. A.; Pruett, R. L.; J. Am. Chem. Soc. 1951, 73, 5506.

27. Simoni, D.; Invidiata, F. P.; Manfrenidi, S.; Ferroni, R.; Lampronti, I.; Roberti, M.; Pollini, G. P.; Tetrahedron Lett. 1997, 38, 2749.

28. Kisanga, P. B.; Verkade, J. G.; J. Org. Chem. 1999, 64, 4298.

29. Jenner, G.; New J. Chem. 1999, 23, 525.

30. Simoni, D.; Rondanin, R.; Morini, M.; Baruchello, R.; Invidiata, F. P.; Tetrahedron Lett. 2000, 41, 1607.

31. Gan, C.; Chen, X.; Lai, G.; Wang, Z.; Synlett 2006, 3, 387.

32. Fabris, M.; Noè, M.; Perosa, A.; Selva, M.; Ballini, R.; J. Org. Chem. 2012, 77, 1805.

33. Gao, M.; Wei, Y.-P.; J. Chem. Res. 2013, 146.

34. Ballini, R.; Gabrielli, S.; Palmieri, A.; Eur. J. Org. Chem. 2014, 9, 1805.

35. Bora, P.; Bora, P. P.; Wahlang, B.; Bez, G.; Can. J. Chem. 2017, 95, 1261 and references cited therein.

36. Dugoni, G. C.; Sacchetti, A; Mele, A.; Org. Biomol. Chem. 2020, 18, 8395 .

37. Palmieri, A.; Gabrielli, S.; Ballini, R.; Beilstein J. Org. Chem. 2013, 9, 533.

38. Natarajan, P.; Chaudhary, R.; Venugopalan, P.; Tetrahedron Lett. 2019, 60, 1720.

39. Anderson, D. A.; Hwu, J. R.; J. Org. Chem. 1990, 55, 511.

40. Tamura, R.; Sato, M.; Oda, D.; J. Org. Chem. 1986, 51, 4375.

41. Tamura, R.; Synth. Org. Chem. 1992, 50, 604.

42. Barton, D. H. R.; Fernandez, I.; Richard, C. S.; Zard, S. Z.; Tetrahedron 1987, 43, 551.

43. Kaim, L. E.; Gacon, A.; Tetrahedron Lett. 1997, 38, 3391.

44. Tamura, R.; Hegedus, L. S.; J. Am. Chem. Soc. 1982, 104, 3127.

45. Ballini, R. Petrini, M.; Adv. Synth. Catal. 2015, 357, 2371.

46. Ballini, R.; Petrini, M.; Tetrahedron 2004, 60, 1017.

47. Kerim, M. D.; Jia, S.; Theodorakidou, C.; Prevost, S.; Ka1m, L. E.; Chem. Commun. 2018, 54, 10917.

48. Ono, N.; Hamamoto, I.; Yanai, T.; Kaji, A.; J. Chem. Soc., Chem. Commun. 1985, 523.

49. Barlaam, B.; Boivin, J.; Zard, S. Z.; Tetrahedron Lett. 1990, 31,7429 .
50. Dumez, E.; Rodriguez, J.; Dulcère, J.-P.; Chem. Commun. 1999, 2009.

51. Alameda-Angulo, C.; Quiclet-Sire, B.; Schmidt, E.; Zard, S. Z.; Org. Lett. 2005, 7, 3489.

52. Chakrapani, H.; Gorczynski, M. J.; King, S. B.; J. Am. Chem. Soc. 2006, 128, 16332.

53. Ono, N.; Hamamoto, I.; Kaji, A.; J. Chem. Soc., Perkin Trans. 1 1986, 1439.

54. Nakano, T.; Miyahara, M.; Itoh, T.; Kamimura, A.; Eur. J. Org. Chem. 2012, 11, 2161.

55. Meirelis, F. P.; Vieira, B. G. N.; Pereira, V. L. P.; Synthesis 2020, 52, 3650.

56. Pereira, V. L. P.; Moura, A. L. S.; Vieira, D. P. P.; Carvalho, L. L.; Torres, E. R. B.; Costa, J. S.; Beilstein J. Org. Chem. 2013, 9, 832.

57. de Carvalho, L. L.; R. A. Burrow, R. A.; Pereira, V. L. P.; Beilstein J. Org. Chem. 2013, 9, 838.

58. Barreto Jr., C. B.; Pereira, V. L. P.; Tetrahedron Lett. 2009, 50, 6389.

59. da Silva, F. P. N. R.; dos Santos, P. F.; da Silva, S. R. B.; Pereira, V. L. P.; J. Braz. Chem. Soc. 2020, 31, 1725.

60. Pennaforte, E. V.; Costa, J. S.; Silva, C. A.; Saraiva, M. C.; Pereira, V. L. P.; Lett. Org. Chem. 2009, 6, 110.

61. Costa, J. S.; Freire, B. S.; Moura, A. L. S.; Pereira, V. L. P.; J. Braz. Chem. Soc. 2006, 17, 1229.

62. Pinto, A. C.; Freitas, C. B. L.; Dias, A. G.; Pereira, V. L. P.; Tinant, B.; Declercq, J.-P.; Costa, P. R. R.; Tetrahedron: Asymmetry 2002, 13, 1025.

63. Silva, P. C.; Costa, J. S.; Pereira, V. L. P.; Synth. Commun. 2001, 31, 595.

64. Costa, J. S.; Dias, A. G.; Anholeto, A. L.; Monteiro, M. D.; Patrocinio, V. L.; Costa, P. R. R.; J. Org. Chem. 1997, 62, 4002.

65. Patrocinio, V. L.; Costa, P. R. R.; Correia, C. R. D.; Synthesis 1994, 5, 474.

66. Simas, A. B. C.; Pereira, V. L. P.; Barreto Jr., C. B.; de Sales, D. L.; de Carvalho, L. L.; Quim. Nova 2009, 32, 2473.

67. Nand, B.; Khanna, G.; Chaudhary, A.; Lumb, A.; Khurana, J. M.; Curr. Org. Chem. 2015, 19, 790.

68. Clark, J. H.; Chem. Rev. 1980, 80, 429.

69. Bosica, G.; Polidano, K.; J. Chem. 2017, 2017, 6267036.

Submitted: January 14, 2021 Published online: April 19, 2021 